\title{
Pengaruh Kepemilikan Manajerial dan Kepemilikan Institusional Terhadap Kinerja Keuangan Perusahaan Dengan Kebijakan Deviden Sebagai Pemoderasi
}

\author{
Mila Nilayanti ${ }^{1}$ \\ I Gst. Ngr. Agung Suaryana ${ }^{2}$ \\ ${ }^{1,2}$ Fakultas Ekonomi dan Bisnis Universitas Udayana (Unud), Bali, Indonesia \\ e-mail: nilayantimila@yahoo.com
}

\begin{abstract}
ABSTRAK
Penelitian ini bertujuan untuk mengetahui pengaruh kepemilikan manajerial dan kepemilikan institusional terhadap kinerja keuangan perusahaan dengan kebijakan deviden sebagai variabel pemoderasi. Lokasi penelitian berada di Bursa Efek Indonesia periode 2012-2016. Populasi penelitian adalah seluruh perusahaan perbankan yang terdaftar di Bursa Efek Indonesia periode 2012-2016. Sampel penelitian dipilih menggunakan metode purposive sampling. Kinerja keuangan perusahaan diukur dengan ROA, kepemilikan manajerial dihitung dengan perbandingan jumlah saham direksi, komisaris, dan manajer dengan jumlah saham beredar, kepemilikan institusional dihitung dengan perbandingan jumlah saham yang dimiliki institusi dengan jumlah saham beredar, dan kebijakan deviden diukur dengan DPR. Teknik analisis data yang digunakan adalah uji statistik deskriptif, uji asumsi klasik, dan MRA. Hasil pengujian menunjukkan kepemilikan manajerial tidak berpengaruh terhadap kinerja keuangan perusahaan, kepemilikan institusional berpengaruh positif terhadap kinerja keuangan perusahaan, kebijakan deviden mampu memperkuat pengaruh kepemilikan institusional terhadap kinerja keuangan perusahaan dan tidak mampu memoderasi pengaruh kepemilikan manajerial terhadap kinerja keuangan perusahaan.

Kata kunci: Kinerja keuangan, kepemilikan manajerial, kepemilikan institusional, kebijakan deviden, perbankan
\end{abstract}

\begin{abstract}
This study aims to determine the effect of managerial and institutional ownership on corporate financial performance with dividend as a moderating variable. The population is all banking companies listed in 2012-2016 periods. The sample was chosen using purposive sampling method. The financial performance is measured by ROA, managerial ownership is calculated by the ratio of shares owned by the manager with the number of shares outstanding, the institutional ownership is calculated by the ratio of shares owned by the institution with the number of shares outstanding, and the dividend measured by the DPR. Data analysis techniques used are descriptive statistical test, classical assumption test, and MRA. Test results show that managerial ownership does not affect the financial performance, institutional ownership positively affects the financial performance, dividend can strengthen the influence of institutional ownership on the financial performance and unable to moderate the effect of managerial ownership on the financial performance.

Keywords: Financial performance, managerial ownership, institutional ownership, dividend policy, banking
\end{abstract}

\section{PENDAHULUAN}

Kinerja suatu bank dapat dinilai dengan melakukan analisis terhadap laporan

keuangannya. Berdasarkan laporan itu dapat dihitung rasio keuangan untuk 
menilai tingkat kesehatan bank. Analisis rasio keuangan tersebut memungkinkan manajemen mengidentifikasi keberhasilan bank dalam melakukan kegiatan operasionalnya. Analisis rasio keuangan juga dapat membantu para pelaku bisnis seperti investor untuk menilai kinerja bank sehingga manajemen perbankan harus selalu mempertahankan kinerja keuangan bank itu sendiri guna meningkatkan laba yang dijadikan sebagai tolak ukur keberhasilan bank itu sendiri.

Peningkatan laba akan menjadi sinyal tersendiri bagi investor untuk menanamkan modalnya. Perkembangan suatu perusahaan sangat bergantung dari modal yang ditanamkan oleh investor, sehingga setiap perusahaan diharuskan untuk memiliki kinerja yang baik guna mendapatkan kepercayaan dari pihak investor untuk menanamkan modalnya. Dalam mempertahankan kinerja keuangan yang baik guna meningkatkan laba dari bank itu sendiri diperlukan kerjasama antara manajemen perusahaan dengan pihak shareholder. Menjalin kerjasama yang baik dalam hal penyatuan kepentingan antara pihak manajemen dan pihak investor sering kali menyebabkan masalah yaitu masalah keagenan.

Masalah keagenan potensial terjadi apabila bagian kepemilikan manajer atas saham perusahaan kurang dari seratus persen (Masdupadi, 2005). Dengan proporsi kepemilikan yang dimiliki manajer hanya sebagian dari perusahaan, membuat manajer cenderung bertindak oportunistik untuk kepentingan pribadinya. Hal ini akan menyebabkan biaya keagenan (agency cost). Jensen dan Meckling (1976) mendefinisikan agency cost sebagai jumlah dari biaya yang dikeluarkan prinsipal untuk melakukan pengawasan terhadap agen. Masalah keagenan dapat diminimalisir dengan meningkatkan kepemilikan saham 
perusahaan oleh manajemen (insider ownership) (Jensen dan Meckling, 1976) dan meningkatkan kepemilikan institusi (institutional investor) sebagai pihak yang memonitor agen (Moh'd, et al, 1998).

Kinerja keuangandari berbagai penelitian sebelumnya, diperoleh kajian mengenai faktor-faktor yang mempengaruhi kinerja keuangan. Faktor-faktor tersebut antara lain: struktur kepemilikan, ukuran perusahaan, good corporate governance, risiko, kesempatan bertumbuh, CAR (Capital Adequacy Ratio), NIM (Net Interest Margin) (Aprianingsih, 2016). Menurut Margaretha dan Asmariani (2009) meningkatkan kepemilikan saham manajerial maupun kepemilikan saham institusional merupakan salah satu cara untuk mengurangi masalah keagenan dan agency cost dalam kontek agency cost model.Menurut Dewi (2008), struktur kepemilikan dipercaya memiliki kemampuan untuk mempengaruhi jalannya perusahaan yang kemudian akan dapat mempengaruhi kinerja perusahaan.

Adanya ketidak konsistenan dari hasil penelitian terdahulu, pada penelitian ini saya menggunakan kebijakan dividen sebagai variabel pemoderasi. Kebijakan dividen merupakan salah satu komponen penting dalam langkah pengambilan keputusan investasi. Hal serupa dinyatakan oleh Jensen dan Meckling (1976), keputusan investasi yang tepat akan menghasilkan return yang tinggi dan berdampak pada peningkatan nilai perusahaan yang tercermin dari kinerja keuangan perusahaan. Jika pembayaran dividen yang tinggi bisa meningkatkan kinerja keuangan perusahaan dan pembayaran dividen yang rendah bisa menurunkan kinerja keuangan perusahaan maka kebijakan dividen dikatakan 
Mila Nilayanti dan I Gst. Ngr. Agung Suaryana. Pengaruh...

mampu memoderasi hubungan kepemilkan manajerial dan kepemilikan institusional terhadap kinerja keuangan perusahaan.

Tahun penelitian 2012-2016 dipilih karena merupakan data terbaru yang tersedia sehingga dapat melihat perkembangan perekonomian terbaru, selain itu adanya fenomena perubahan kebijakan BI Rate yang efektif sejak bulan Agustus tahun 2016 menjadi BI 7-Day (Reverse) Rapo Rate. Data tahun 2017 tidak digunakan dalam penelitian ini karena ketidak lengkapan data dividen pada tahun 2017. Mayoritas emiten perbankan dalam sampel penelitian belum melakukan RUPS sehingga belum dapat dipastikan apakah emiten perbankan tersebut akan mengeluarkan dividen atau tidak, hal tersebut menyebabkan tahu 2017 tidak termasuk dalam tahun penelitian.

Rumusan masalah dari penelitian ini adalah apakah kepemilikan manajerial berpengaruh terhadap kinerja keuangan perusahaan. Apakah kepemilikan institusional berpengaruh terhadap kinerja keuangan perusahaan.Apakah kebijakan dividen dapat memengaruhi pengaruh kepemilikan manajerial terhadap kinerja keuangan perusahaan. Apakah kebijakan dividen dapat memengaruhi pengatuh kepemilikan institusional terhadap kinerja keuangan perusahaan.Berdasarkan rumusan masalah yang telah dipaparkan tersebut, maka tujuan dari penelitian ini adalah untuk mendapatkan bukti empiris pengaruh kepemilikan manajerial terhadap kinerja keuangan perusahaan. Untuk mendapatkan bukti empiris pengaruh kepemilikan institusional terhadap kinerja keuangan perusahaan.Untuk mendapatkan bukti empiris kebijakan dividen dapat memengaruhi pengaruh kepemilikan manajerial terhadap kinerja keuangan 
perusahaan.Untuk mendapatkan bukti empiris kebijakan dividen dapat memengaruhi pengaruh kepemilikan institusional terhadap kinerja keuangan perusahaan.

Penelitian ini diharapkan dapat memberikan kegunaan kegunaan teoritis yaitu memberikan bukti empiris teori keagenan dan teori sinyal berdasarkan hasil penelitian kepemilikan institusional berpengaruh terhadap kinerja keuangan perusahaandan kebijakan dividen mampu memoderasi dan memperkuat pengaruh kepemilikan institusional terhadap kinerja keuangan perusahaan. Kegunaan praktis bagi perbankan yaitu memiliki peran penting dalam meningkatkan kinerja keuangan perusahaan. Peran ini semakin kuat dengan adanya kebijakan dividen. Perusahaan perbankan sebaiknya memperhatikan kepemilikan institusional dan kebijakan dividen dalam meningkatkan kinerja keuangan perusahaan. Kegunaan praktis bagi pengguna laporan keuangan diharapkan memperhatikan kepemilikan institusional dan kebijakan dividen perusahaan dalam mengambil keputusan investasi.

Manajer sebagai agen tentunya akan mengetahui lebih banyak mengenai kondisi perusahaan dibandingkan dengan investor sebagai prinsipal. Dikarenakan manajer mempunyai informasi yang lebih superior menyebabkan manajer wajib untuk menyampaikan kondisi perusahaan kepada investor. Informasi yang disampaikan oleh manajer terkadang tidak seperti yang sebenarnya terjadi pada perusahaan. Menurut Haris Wibisono (2004: 22), kondisi ini yang disebut dengan informasi yang tidak simetris atau asimetri informasi. Asimetri informasi dapat memberikan kesempatan bagi manajer untuk bertindak opportnistic untuk 
Mila Nilayanti dan I Gst. Ngr. Agung Suaryana. Pengaruh...

memaksimalkan kepentingan pribadinya tanpa persetujuan pemilik atau pemegang saham dan memberikan kesempatan bagi manajer untuk melakukan manajemen laba dalam rangka menyesatkan pemilik atau pemegang saham mengenai kinerja keuangan pada perusahaan (Vernon, 1998: 24).

Terdapat bukti empiris bahwa jika ada kenaikan dividen, sering diikuti dengan kenaikan harga saham. Sebaliknya penurunan dividen pada umumnya menyebabkan harga saham turun (Dermawan, 2008:313). Menurut Modigliani dan Miller (1963) mengatakan bahwa suatu kenaikan dividen lebih besar dari yang sebelumnya merupakan sinyal kepada investor bahwa manajemen perusahaan meramalkan suatu penghasilan yang baik dimasa yang akan datang. Menurut Wolk dan Tearney (1997) signaling theory didasarkan pada suatu informasi yang bersifat asimetri antara pihak dalam dan luar perusahaan. Menurut Morris (1987), teori sinyal menunjukkan bahwa dampak asimetri informasi yang menjadi masalah utama dapat diminimalisir dengan memberikan tambahan informasi lebih yang dapat dianggap sebagai sinyal oleh pihak eksternal perusahaan. Melakukan pengungkapan yang lebih tentang modal intelektual yang dimiliki perusahaan, diharapkan dapat mengirimkan sinyal good news kepada pihak eksternal perusahaan bahwa perusahaan saat ini sedang berinventasi dalam bentuk modal intelektual yang diharapkan akan memberikan keuntungan ekonomi untuk perusahaan dimasa yang akan datang sehingga dapat meningkatkan nilai perusahaan (Marisanti, 2012).

Menurut Undang-Undang RI Nomor 10 Tahun 1998 tanggal 10 November 1998 tentang Perbankan, yang dimaksud dengan bank adalah badan usaha yang 
menghimpun dana dari masyarakat dalam bentuk simpanan dan menyalurkannya kepada masyarakat dalam bentuk kredit dan atau bentuk-bentuk lainnya dalam rangka meningkatkan taraf hidup rakyat banyak. Menurut Darmawi (2006), peranan bank umum dalam perekonomian adalah menyediakan berbagai jasa perbankan, sebagai jantungnya perekonomian dan melaksanakan kebijakan moneter.

Menurut Tarigan dkk., (2007), kepemilikan manajerial adalah kondisi dimana manajer yang bertindak sebagai agen tetapi juga mendapatkan hak atas kepemilikan saham perusahaan. Menurut Almilia dkk., (2006: 2), tindakan manajer dalam mengoperasikan perusahaan seringkali melakukan tindakan oportunistik untuk memaksimalkan utilitasnya dan bukan untuk kemakmuran investor. Ross (1977) menyatakan bahwa kecenderungan manajemen perusahaan yang memiliki jumlah kepemilikan manajerial yang besar akan membuat kinerja manajer semakin baik didorong oleh kepentingannya yang sama dengan investor.

Menurut Widarjo (2010), kepemilikan institusional merupakan kondisi dimana institusi memiliki saham dalam suatu perusahaan. Institusi tersebut dapat berupa institusi pemerintah, institusi swasta, domestik maupun asing. Menurut Widiastuti dkk.,(2013: 3403), kepemilikan institusional merupakan kepemilikan saham oleh lembaga eksternal. Investor institusional sering kali menjadi pemilik mayoritas dalam kepemilikan saham, karena para investor institusional memiliki sumber daya yang lebih besar daripada pemegang saham lainnya sehingga dianggap mampu melaksanakan mekanisme pengawasan yang baik. Sebagai pemegang saham pengendali, kepemilikan institusional pada umumnya akan 
melakukan fungsi pengawasan dalam perusahaan. Bushee (1998) dalam Siregar dan Utama (2005) menyatakan bahwa kepemilikan institusional melakukan fungsi pengawasan sebagai pendorong agar pihak manajer tidak malakukan tindakan oportunistik yang dapat merugikan perusahaan dalam jangka panjang.

Dividen merupakan sinyal dan stabilitas aliran kas dimasa mendatang. Perusahaan yang memiliki aliran kas stabil membayar dividen lebih tinggi dibandingkan perusahaan perusahaan yang memiliki aliran kas tidak stabil (Ratnawati, 2001).Kemampuan perusahaan dalam menghasilkan laba merupakan salah satu indikator penting untuk menilai kinerja keuangan sebuah perusahaan. sehingga, pembayaran dividen akan dipengaruhi oleh olehfluktuasitingkat keuntungantahunandicapai (Manneh dan Naser, 2015). Menurut Martono dan Harjito (2000:253) kebijakan dividen merupakan bagian yang tidak dapat dipisahkan dengan keputusan pendanaan. Kebijakan dividen memiliki hubungan dengan biaya keagenan yang telah menjadi fokus untuk menjelaskan pembayarandividen dapat digunakan untuk mengontrol biaya keagenan dari perusahaan (Nafi'ah, 2013).Kebijakan dividen berfungsi sebagai mekanisme pengendalian dari sikap oportunisme manajerial (Adediran dan Alade, 2013).

Menurut Fahmi (2012: 2), kinerja keuangan adalah salah satu metode analisis yang digunakan perusahaan untuk mengukur efektifitas dan kepatuhan dengan menggunakan aturan-aturan keuangan sebagai basis pelaksanaan keuangan yang baik dan benar. Salah satu contohnya adalah perusahaan membuat pelaporan keuangan berdasarkan SAK (Standar Akuntansi Keuangan) yang berlaku. Menurut Jumingan (2009: 239), kinerja bank secara keseluruhan 
merupakan salah satu cara untuk menilai pencapaian yang telah dicapai bank dalam suatu periode menyankut segala aspek operasional bank. Menurut Rivai (2012: 459), penilaian kinerja perbankan meliputi seluruh aspek operasional maupun non-operasional bank tersebut. Penilaian kinerja keuangan perusahaan umumnya berfokus pada informasi yang berasal dari laporan keuangan dan diukur dengan berbagai macam indikator maupun variabel dalam mengukur keberhasilan suatu perusahaan (Purwantini, 2008).

Penelitian yang dilakukan oleh Waskito (2014) menyatakan bahwa variabel kepemilikan manajerial berpengaruh positif dan signifikan terhadap variabel kinerja keuangan perusahaan. Penelitian oleh Hermiyetti dan Katlanis (2017) diperoleh hasil bahwa kepemilikan manajerial dan kepemilikan istitusional memiliki pengaruh positif dan signifikan terhadap kinerja keuangan perusahaan.Penelitian yang dilakukan oleh Indarti dan Extaliyus (2013) mendapatkan hasil, yaitu kepemilikan manajerial berpengaruh positif signifikan terhadap kinerja keuangan perusahaan Hasil penelitian dari Umalomwa dan Olamide (2012) menunjukan bahwa kepemilikan manajerial berpengaruh positif signifikan terhadap kinerja perusahaan.

$\mathrm{H}_{1}$ : Kepemilikan Manajerial berpengaruh positif terhadap Kinerja Keuangan Perusahaan

Penelitian yang dilakukan oleh Dewi (2017) menyatakan bahwa variabel kepemilikan institusional berpengaruh positif dan signifikan terhadap variabel kinerja keuangan perusahaan. Penelitian oleh Hermiyetti dan Katlanis (2017) diperoleh hasil bahwa kepemilikan manajerial dan kepemilikan istitusional memiliki pengaruh positif dan signifikan terhadap kinerja keuangan 
Mila Nilayanti dan I Gst. Ngr. Agung Suaryana. Pengaruh...

perusahaan.Penelitian oleh Affes (2013) menunjukkan bahwa kepemilikan institusional berpengaruh positif dan signifikan terhadap kinerja keuangan perusahaan. Penelitian yang dilakukan olehAbbasi et al. (2012) menyimpulkan bahwa kepemilikan institusional berpengaruh positif terhadap kinerja keuangan.

$\mathrm{H}_{2}$ : Kepemilikan Institusional berpengaruh positif terhadap Kinerja Keuangan Perusahaan

Kebijakan dividen memiliki hubungan dengan biaya keagenan yang telah menjadi fokus untuk menjelaskan pembayarandividen dapat digunakan untuk mengontrol biaya keagenan dari perusahaan (Nafi'ah, 2013).Penelitian yang diakukan oleh Vidyantie dan Handayani (2006) mendapatkan hasil bahwa kebijakan dividen dan kepemilikan manajerial memiliki hubungan yang posistif. Dividen yang tinggi dapat memberikan manajer tingkat kepercayaan yang tinggi sehingga dapat meningkatkan pendapatan perusahaan dimasa mendatang (Imanta dan Satwiko, 2011).

$\mathrm{H}_{3}$ : Kebijakan dividen mampu secara signifikan memoderasi hubungan kepemilikan manajerial terhadap kinerja keuangan perusahaan.

Menurut Jama'an (2008) Signaling Theory mengemukakan tentang bagaimana seharusnya sebuah perusahaan memberikan sinyal kepada pengguna laporan keuangan. Penelitian yang dilakukan oleh Ismiyanti dan Hanafi (2003) mendapatkan hasil bahwa kebijakan dividen dan kepemilikan institusional memiliki hubungan yang positif.

$\mathrm{H}_{4}$ : Kebijakan dividen mampu secara signifikan memoderasi hubungan kepemilikan institusional terhadap kinerja keuangan perusahaan. 
ISSN: 2302-8556

E-Jurnal Akuntansi Universitas Udayana

Vol.26.2.Februari (2019): 906-936

\section{METODE PENELITIAN}

Penelitian ini menggunakan pendekatan yang bersifat kuantitatif yang berbentuk asosiatif. Pada penelitian ini, variabel yang diteliti adalah kepemilikan manajerial $\left(\mathrm{X}_{1}\right)$, kepemilikan institusional $\left(\mathrm{X}_{2}\right)$ sebagai variabel bebas, kebijakan dividen $\left(\mathrm{X}_{3}\right)$ sebagai variabel pemoderasi, dan kinerja keuangan perusahaan $(\mathrm{Y})$ sebagai variabel terikat. Lokasi penelitian ini dilakukan pada seluruh perusahaan perbankan yang terdaftar di Bursa Efek Indonesia tahun 2012-2016 yang diakses resmi di situs Bursa Efek Indonesia (www.idx.co.id). Objek dalam penelitian ini adalah kinerja keuangan perusahaan perbankan yang terdaftar di Bursa Efek Indonesia periode 2012-2016. Perusahaan perbankan dipilih karena sektor perbankan merubah kebijakannya yang semula BI rate menjadi BI 7-days reporate.

Variabel Kepemilikan Manajerial dihitung dengan rumus sebagai berikut.

$$
\text { MNJR }=\frac{\text { Jumlah saham direksi,komisaris,dan manajer }}{\text { Jumlah saham yang beredar }} .
$$

Kepemilikan institusional merupakan bagian dari saham perusahaan yang dimiliki oleh institusi ataupun perusahaan lain, yang dihitung berdasarkan penjumlahan atas persentase saham perusahaan yang dimiliki oleh perusahaan lain (Sam'ani, 2008). Variabel Kepemilikan Institusional dihitung dengan rumus sebagai berikut:

INST $=\frac{\text { Jumlah saham yang dimiliki institusi }}{\text { Jumlah saham yang beredar }}$

Variabel Kebijakan Dividen dihitung dengan rumus sebagai berikut:

Dividend Payout Ratio $(D P R)=\frac{\text { Dividend }}{\text { Net Profit }}$ 
Menurut Brigham \& Houston (2012: 148), Return On Asset (ROA) merupakan rasio yang digunakan untuk mengukur tingkat pengembalian total aset yang digunakan dan biasa digunakan sebagai indikator tingkat profitabilitas.

Return On Asset $(R O A)=\frac{\text { Laba Bersih }}{\text { Aset }}$

Populasi dalam penelitian ini adalah seluruh perusahaan perbankan yang terdaftar di Bursa Efek Indonesia periode 2012-2016.Sampel adalah bagian dari jumlah karakteristik yang dimiliki oleh populasi tersebut (Sugiyono, 2014:116). Pemilihan sampel penelitian didasarkan pada metode puposive sampling, yaitu teknik penentuan sampel untuk tujuan tertentu saja (Sugiyono, 2014:85). Kriteria yang dipertimbangan dalam pengambilan sampel penelitian ini adalah perusahaan mempublikasi laporan keuangan secara berturut-turut sesuai dengan periode pengamatan 2012-2016 dan Perusahaan mengungkapkan data mengenai kepemilikan manajerial, kepemilikan institusional, dan kebijakan dividen selama periode pengamatan 2012-2016.

Metode pengumpulan data yang digunakan pada penelitian ini adalah metode observasi nonpartisipan. Pengumpulan data penelitian ini dilakukan dengan cara melakukan pengamatan terhadap laporan keuangan tahunan perusahaan perbankan yang terdaftar di Bursa Efek Indonesia periode 20122016.Jenis data yang digunakan dalam penelitian ini adalah data kuantitatif. Jenis data yang digunakan dalam penelitian ini adalah laporan keuangan perusahaan perbankan yang terdaftar di Bursa Efek Indonesia periode 2012-2016.Sumber data yang digunakan dalam penelitian ini adalah data sekunder yang diperoleh dari laporan keuangan perusahaan perbankan yang terdaftar di Bursa Efek Indonesia 
periode 2012-2016 yang dapat diakses melalui website www.idx.co.id dan The Indonesian Capital Market Institute (TICMI) melalui website resmi www.ticmi.co.id serta melalui bank data TICMI dengan mengirim permohonan data ke e-mailinfo@ticmi.co.id.

Uji asumsi klasik perlu dilakukan terlebih dahulu terhadap variabel-variabel yang ada agar tidak terjadi bias dalam pengujian yang dilakukan. Uji asumsi klasik ini meliputi uji normalitas digunakan untuk menguji apakah data variabel independen dan data variabel dependen pada persaman regresi berdistribusi normal atau tidak. Uji normalitas yang digunakan dalam penelitian ini menggunakan Kolmogorov-Smirnov. Penelitian ini menggunakan taraf signifikansi 5persen dengan melihat signifikansi (Asymp. Sig. pada output Statistikal Package for Social Science) dari nilai Kolmogorov-Smirnov > 5persen, maka data yang digunakan berdistribusi normal (Ghozali, 2011: 164).Uji heterokedastisitas bertujuan untuk mengatahui dan menguji apakah dalam model regresi terjadi ketidaksamaan variance dari residual satu pengamatan ke residual pengamatan lainnya. Metode yang digunakan untuk mendeteksi ada atau tidaknya heterokedastisitas dilakukan dengan melihat Sig dengan kriteria nilai harus lebih besar daripada taraf signifikansi 0,05 atau 5 persen.Uji autokorelasi digunakan untuk menguji model regresi linier tentang pengaruh data dari pengamatan sebelumnya. Uji autokorelasi dapat dilakukan dengan uji Durbin-Watson. Kriteria pengujian adalah dengan melihat Sig (2-tailed) lebih besar dari 0,05 atau 5persen (Utama, 2009:102). 
Moderated Regression Analysis (MRA) yang merupakan analisis dalam penelitian inidigunakan untuk memperoleh gambaran mengenai pengaruh kepemilikan manajerial dan kepemilikan institusional berpengaruh pada kinerja keuangan perusahaan serta untuk menentukan apakah pemoderasi yaitu kebijakan dividen mempengaruhi hubungan antar variabel yaitu variabel terikat dan variabel bebas. Keunggulan dari uji interaksi ini adalah untuk mendapatkan hasil atas variabel moderasinya apakah memperkuat atau memperlemah pengaruh variabel terikat pada variabel bebas. Model MRA dapat dilihat pada persamaan statistik seperti berikut.

$Y=\alpha+\beta_{1} X_{1}+\beta_{2} X_{2}+\beta_{3} X_{3}+\beta_{4} X_{1} * X_{3}+\beta_{5} X_{2} * X_{3}+e$

Keterangan:

$\mathrm{Y}=$ Kinerja Keuangan Perusahaan

$\alpha=$ Konstanta

$\mathrm{X}_{1}=$ Kepemilikan Manajerial

$\mathrm{X}_{2}=$ Kepemilikan Institusional

$\mathrm{X}_{3}=$ Kebijakan Dividen

$\mathrm{X}_{1} * \mathrm{X}_{3}=$ Interaksi antara kepemilikan manajerial dan kebijakan dividen

$\mathrm{X}_{2} * \mathrm{X}_{3}=$ Interaksi antara kepemilikan institusional dan kebijakan dividen

$\beta_{1}, \beta_{2}, \beta_{3}, \beta_{4}$, dan $\beta_{5}=$ Koefisien regresi

$\mathrm{e}=$ Error

\section{HASIL DAN PEMBAHASAN}

Bursa Efek Indonesia merupakan lembaga pemerintah yang menjembatani entitas dengan dana lebih dengan emiten yang membutuhkan dana. Bursa Efek Indonesia (BEI) atau Indonesia Stock Exchange (IDX) merupakan hasil penggabungan dari Bursa Efek Jakarta dengan Bursa Efek Surabaya. Populasi penelitian ini adalah seluruh perusahaan dalam sektor perbankan dikarnakan terjadinya perubahan 
ISSN: 2302-8556

E-Jurnal Akuntansi Universitas Udayana Vol.26.2.Februari (2019): 906-936

kebijakan keuangan BI Rate menjadi BI 7-Day Rapo Rate. Sampel pada penelitian ini dipilih berdasarkan teknik purposive sampling.

Tabel 1. Sampel Penelitian

\begin{tabular}{clc}
\hline No & \multicolumn{1}{c}{ Kriteria } & Jumlah \\
\hline 1 & $\begin{array}{l}\text { Emiten terdaftar di Bursa Efek Indonesia dan termasuk dalam } \\
\text { sektor perbankan pada periode penelitian 2012-2016. }\end{array}$ & 44 \\
2 & $\begin{array}{l}\text { Perusahaan mempublikasi laporan keuangan secara berturut-turut } \\
\text { sesuai dengan periode pengamatan 2012-2016 }\end{array}$ \\
& $\begin{array}{l}\text { Perusahaan mengungkapkan data mengenai kepemilikan } \\
\text { manajerial, kepemilikan institusional, dan kebijakan dividen } \\
\text { selama periode pengamatan 2012-2016. } \\
\text { Total Sampel Penelitian }\end{array}$ \\
\hline Sumber: Data diolah, 2018
\end{tabular}

Populasi pada penelitian ini sebanyak 44 perusahaan yaitu perusahaan perbankan yang terdaftar di Bursa Efek Indonesia pada periode penelitian 20122016. Perusahaan yang masuk pada sampel penelitian diseleksi sesuai dengan kriteria yang telah ditetapkan sebanyak 31 perusahaan.

Tabel 2.

Hasil Analisis Statistik Deskriptif

\begin{tabular}{lrcccc}
\hline \multicolumn{1}{c}{ Variabel } & N & \multicolumn{1}{c}{ Min. } & \multicolumn{1}{c}{ Max. } & \multicolumn{1}{c}{ Mean } & Std. Deviasi \\
\hline Kepemilikan Manajerial $\left(\mathrm{X}_{1}\right)$ & 145 & 0,00000 & 0,12546 & 0,0041290 & 0,01876455 \\
Kepemilikan Institusional $\left(\mathrm{X}_{2}\right)$ & 145 & 0,11032 & 0,99997 & 0,7423074 & 0,20962639 \\
Kebijakan Dividen $\left(\mathrm{X}_{3}\right)$ & 145 & 0,00000 & 0,74790 & 0,1372378 & 0,18158967 \\
Kinerja Keuangan Perusahaan $(\mathrm{Y})$ & 145 & $-5,13000$ & 3,84000 & 1,2053103 & 1,13784461 \\
\hline
\end{tabular}

Sumber: Data diolah, 2018

Tabel 2menunjukkan besarnya variabel kepemilikan manajerial $\left(\mathrm{X}_{1}\right)$ berkisar antara 0,00000 hingga 0,12546 dengan nilai mean sebesar 0,0041290 dan standar deviasi sebesar 0,1876455 . Perusahaan perbankan yang memiliki nilai kepemilikan manajerial terendah adalah sebanyak 82 perusahaan mulai dari tahun 2012-2016 sebesar 0,0000 yang bermakna bahwa 82 perusahaan pada sampel penelitian memiliki proporsi kepemilikan manajerial sebesar 0persensedangkan perusahaan perbankan dengan nilai kepemilikan manajerial tertinggi adalah PT Bank Central Asia Tbk sebesar 0,12546 pada tahun 2016 yang bermakna bahwa 
pada tahun 2016, PT Bank Central Asia Tbk menjadi perusahaan pada sampel penelitian yang memiliki proporsi kepemilikan manajerial tertinggi yaitu sebesar 12,546persen.Variabel kepemilikan institusional $\left(\mathrm{X}_{2}\right)$ memiliki nilai yang berkisar antara 0,11032 hingga 0,99997 dengan nilai mean sebesar 0,7423074 dan standar deviasi sebesa r0,20962639. Perusahaan perbankan yang memiliki nilai kepemilikan institusional terendah adalah PT Bank Himpunan Saudara 1906 Tbk sebesar 0,11032 pada tahun 2012 yang bermakna bahwa pada tahun 2012, PT Bank Himpunan Saudara 1906 Tbk memiliki proporsi kepemilikan institusional paling rendah pada sampel penelitian yaitu sebesar 11,032 persensedangkan perusahaan perbankan dengan nilai kepemilikan institusional tertinggi adalah PT Bank Mutiara Tbk sebesar 0,99997 pada tahun 2015 yang bermakna bahwa pada tahun 2015, PT Bank Mutiara Tbk memiliki proporsi kepemilikan institusional paling tinggi pada sampel penelitian yaitu sebesar 99,997persen.

Variabel kebijakan dividen $\left(\mathrm{X}_{3}\right)$ memiliki nilai yang berkisar antara 0,00000 hingga 0,74790 dengan nilai mean sebesar 0,1372378 dan standar deviasi sebesar 0,18158967. Perusahaan perbankan yang memiliki nilai kebijakan dividen terendah adalah sebanyak 82 perusahaan dengan nilai sebesar 0,00000 pada tahun 2012-2016yang bermakna bahwa 82 perusahaan pada sampel penelitian memiliki nilai dividend payout ratio paling rendah yaitu sebesar 0persensedangkan perusahaan perbankan dengan nilai kebijakan dividen tertinggi adalah PT Bank Bjb Tbk sebesar 0,74790 pada tahun 2016 yang bermakna bahwa pada tahun 2016, PT Bank Bjb Tbk memiliki nilai dividend payout ratio paling tinggi pada sampel penelitian yaitu sebesar 74,790 persen. Variabel kinerja keuangan 
ISSN: 2302-8556

E-Jurnal Akuntansi Universitas Udayana Vol.26.2.Februari (2019): 906-936

perusahaan (Y) memiliki nilai yang berkisar antara $-5,13000$ hingga 3,84000 dengan nilai mean sebesar 1,2053103 dan standar deviasi sebesar 1,13784461. Perusahaan perbankan yang memiliki nilai kinerja keuangan perusahaan terendah adalah PT Bank Mutiara Tbk sebesar -5,13000 pada tahun 2015 yang bermakna bahwa pada tahun 2015, PT Bank Mutiara Tbk memiliki nilai return on asset paling rendah dalam sampel penelitian yaitu sebesar $-5,13$ persensedangkan perusahaan perbankan dengan nilai kinerja keuangan perusahaan tertinggi adalah PT Bank Rakyat Indonesia sebesar 3,84000 pada tahun 2012 yang bermakna bahwa pada tahun 2012, PT Bank Rakyat Indonesia memiliki nilai return on asset paling tinggi dalam sampel penelitian yaitu sebesar 3,84 persen.

Tabel 3.

Hasil Uji Normalitas

\begin{tabular}{ccccc}
\hline No & Persamaan & $\mathbf{N}$ & $\begin{array}{c}\text { Kolmogorov } \\
\text { Smirnov } \boldsymbol{Z}\end{array}$ & $\begin{array}{c}\text { Asymp. Sig. (2- } \\
\text { tailed) }\end{array}$ \\
\hline 1 & $\mathrm{Y}=\alpha+\beta_{1} X_{1}+\beta_{2} X_{2}+\mathrm{e}$ & 145 & 1,112 & 0,168 \\
\hline
\end{tabular}

Sumber: Data diolah, 2018

Tabel 3 menunjukkan hasil bahwa nilai signifikansi sebesar 0,168 >0,05.

Hal ini menunjukkan bahwa model regresi pada penelitian ini berdistribusi normal

Tabel 4.

Hasil Uji Heteroskedastisitas

\begin{tabular}{lccccc}
\hline \multirow{2}{*}{ Variabel } & \multicolumn{2}{c}{$\begin{array}{c}\text { Unstandardized } \\
\text { Coefficients }\end{array}$} & $\begin{array}{c}\text { Standardized } \\
\text { Coefficients }\end{array}$ & t & \multirow{2}{*}{ Sig. } \\
\cline { 2 - 4 } & $\mathbf{B}$ & $\begin{array}{c}\text { Std. } \\
\text { Error }\end{array}$ & Beta & & \\
\cline { 2 - 5 } & 0,476 & 0,062 & & 7,733 & 0,000 \\
Kepemilikan Manajerial $\left(\mathrm{X}_{1}\right)$ & $-2,761$ & 24,272 & $-0,104$ & $-0,114$ & 0,910 \\
Kepemilikan Institusional $\left(\mathrm{X}_{2}\right)$ & $-0,007$ & 0,021 & $-0,028$ & $-0,336$ & 0,737 \\
Kebijakan Dividen $\left(\mathrm{X}_{3}\right)$ & $-9,328$ & 5,160 & $-3,413$ & $-1,808$ & 0,073 \\
$\left(\mathrm{X}_{1}\right) *\left(\mathrm{X}_{3}\right)$ & $-1,734$ & 34,042 & $-0,045$ & $-0,051$ & 0,959 \\
$\left(\mathrm{X}_{2}\right) *\left(\mathrm{X}_{3}\right)$ & 9,412 & 5,406 & 3,349 & 1,741 & 0,084 \\
\hline
\end{tabular}

Sumber: Data diolah, 2018 
Mila Nilayanti dan I Gst. Ngr. Agung Suaryana. Pengaruh...

Berdasarkan Tabel 4 menunjukkan signifikansi t setiap variabel bebas diatas 0,05 atau Sig.> 0,05sehingga dapat disimpulkan model regresi penelitian ini bebas dari gejala heteroskedastisitas.

Tabel 5.

Hasil Uji Autokorelasi

\begin{tabular}{ccc}
\hline Model & $\begin{array}{c}\text { Adjusted } \\
\boldsymbol{R} \text { Square }\end{array}$ & $\begin{array}{c}\text { Durbin- } \\
\text { Watson }\end{array}$ \\
\hline 1 & 0,110 & 1,879 \\
\hline
\end{tabular}

Sumber: Data diolah, 2018

Berdasarkan Tabel 5 menunjukkan bahwa nilai dU untuk 145 sampel dengan tiga variabel adalah 1.771 dengan nilai Durbin-Watson sebesar 1.879 . Data lolos uji autokorelasi jika dU $<$ DW < 4-dU. Berdasarkan Tabel 5 maka, $1.771<1.879<2.229$ dengan demikian data lolos uji autokorelasi.

Tabel 6.

Hasil Moderated Regression Analysis

\begin{tabular}{|c|c|c|c|c|c|c|}
\hline \multirow{2}{*}{ Variabel } & \multicolumn{2}{|c|}{$\begin{array}{l}\text { Unstandardized } \\
\text { Coefficients } \\
\end{array}$} & \multirow{2}{*}{$\begin{array}{c}\begin{array}{c}\text { Standardized } \\
\text { Coefficient }\end{array} \\
\text { Beta }\end{array}$} & \multirow{2}{*}{$\mathbf{T}$} & \multirow{2}{*}{ Sig. } & \multirow{2}{*}{ Ket. } \\
\hline & B & $\begin{array}{c}\text { Std. } \\
\text { Error }\end{array}$ & & & & \\
\hline (Constant) & $-1,663$ & 0,252 & & $-6,605$ & 0,000 & \\
\hline $\mathrm{X}_{1}$ & $-2,545$ & 31,581 & $-0,042$ & $-0,081$ & 0,936 & $\mathrm{H}_{1}$ ditolak \\
\hline $\mathrm{X}_{2}$ & 3,754 & 0,402 & 0,692 & 9,346 & 0,000 & $\mathrm{H}_{2}$ diterima \\
\hline$X_{3}$ & $-24,565$ & 7,112 & $-3,920$ & $-3,454$ & 0,001 & \\
\hline$\left(\mathrm{X}_{1}\right) *\left(\mathrm{X}_{3}\right)$ & $-5,515$ & 44,319 & $-0,063$ & $-0,124$ & 0,901 & $\mathrm{H}_{3}$ ditolak \\
\hline$\left(\mathrm{X}_{2}\right) *\left(\mathrm{X}_{3}\right)$ & 26,936 & 7,325 & 4,181 & 3,677 & 0,000 & $\mathrm{H}_{4}$ diterima \\
\hline $\mathrm{R}^{2}$ & & & 0,681 & & & \\
\hline F Hitung & & & 62,614 & & & \\
\hline Sig. F & & & 0,000 & & & \\
\hline
\end{tabular}

Sumber: Data diolah, 2018

Persamaan regresi yang dihasilkan melalui moderated regression analysis (MRA) adalah sebagai berikut:

$Y=-1,663-2,545 X_{1}+3,754 X_{2}-24,565 X_{3}-5,515 X_{1} X_{3}+26,936 X_{2} X_{3}+e$

Nilai konstanta $(\alpha)$ sebesar -1,663. Hal ini menunjukkan bahwa jika variabel kepemilikan manajerial, kepemilikan institusional, kebijakan dividen, interaksi 
antara kepemilikan manajerial dengan kebijakan dividen, dan interaksi antara kepemilikan institusional dengan kebijakan dividen dinyatakan konstan pada angka 0 , maka nilai kinerja keuangan perusahaan akan menurun sebesar 1,663.Nilai koefisien $\left(\beta_{1}\right)$ sebesar -2,545. Hal ini menunjukkan bahwa jika kepemilikan manajerial meningkat satu satuan, maka kinerja keuangan perusahaan akan menurun sebesar 2,545 dengan asumsi veriabel bebas lainnya dianggap konstan.Nilai koefisien $\left(\beta_{2}\right)$ sebesar 3,754. Hal ini menunjukkan bahwa jika kepemilikan institusional meningkat satu satuan, maka kinerja keuangan perusahaan akan meningkat sebesar 3,754 dengan asumsi veriabel bebas lainnya dianggap konstan.Nilai koefisien $\left(\beta_{3}\right)$ sebesar $-24,565$. Hal ini menunjukkan bahwa jika kebijakan dividen meningkat satu satuan, maka kinerja keuangan perusahaan akan menurun sebesar 24,565 dengan asumsi veriabel bebas lainnya dianggap konstan.Nilai koefisien $\left(\beta_{4}\right)$ interaksi antara kepemilikan manajerial dengan kebijakan dividen sebesar -5,515. Hal ini menunjukkan bahwa jika interaksi antara kepemilikan manajerial dengan kebijakan dividen meningkat satu satuan, maka kinerja keuangan perusahaan akan menurun sebesar 5,515 dengan asumsi veriabel bebas lainnya dianggap konstan.Nilai koefisien $\left(\beta_{5}\right)$ interaksi antara kepemilikan institusional dengan kebijakan dividen sebesar 26,936. Hal ini menunjukkan bahwa jika interaksi antara kepemilikan institusional dengan kebijakan dividen meningkat satu satuan, maka kinerja keuangan perusahaan akan meningkat sebesar 26,936 dengan asumsi veriabel bebas lainnya dianggap konstan. 
Berdasarkan Tabel 6 nilai koefisien determinasi $\left(\mathrm{R}^{2}\right)$ sebesar 0,681 atau 68,1persen yang dilihat dari nilai adjusted $\mathrm{R}$ square. Nilai sebesar 68,1persen menunjukkan bahwa kinerja keuangan perusahaan (Y) dapat dijelaskan oleh variabel kepemilikan manajerial $\left(\mathrm{X}_{1}\right)$, kepemilikan institusional $\left(\mathrm{X}_{2}\right)$, interaksi antara kepemilikan manajerial degan kebijakan dividen $\left(\mathrm{X}_{1} \mathrm{X}_{3}\right)$, dan interaksi antara kepemilikan institusional dengan kebijakan dividen $\left(\mathrm{X}_{2} \mathrm{X}_{3}\right)$, sedangkan sisanya 31,9persen dipengaruhi oleh factor lain yang tidak dijelaskan dalam model.Berdasarkan Tabel 6 dapat dilihat bahwa nilai signifikansi yang diperoleh adalah sebesar 0,000. Nilai signifikansi 0,000 lebih kecil dari tingkat signifikansi 0,05 atau nilai sig. $0,000<0,05$ yang memiliki arti bahwa model regresi yang dibuat layak untuk digunakan.

Berdasarkan Tabel 6, maka hasil uji t dapat diartikan kepemilikan manajerial $\left(\mathrm{X}_{1}\right)$ memiliki nilai signifikansi sebesar 0,936. Nilai signifikansi sebesar 0,936 lebih besar dari tingkat signifikansi 0,05 atau nilai Sig. 0,936 > 0,05, sehingga dapat dikatakan bahwa $\mathrm{H}_{1}$ ditolak. Hal ini berarti bahwa kepemilikan manajerial $\left(\mathrm{X}_{1}\right)$ tidak berpengaruh terhadap kinerja keuangan perusahaan (Y) secara parsial.Kepemilikan institusional $\left(\mathrm{X}_{2}\right)$ memiliki nilai signifikansi sebesar 0,000. Nilai signifikansi sebesar 0,000 lebih kecil dari tingkat signifikansi 0,05 atau nilai Sig. $0,000<0,05$, sehingga dapat dikatakan bahwa $\mathrm{H}_{2}$ diterima. Hal ini berarti bahwa kepemilikan institusional $\left(\mathrm{X}_{2}\right)$ berpengaruh positif terhadap kinerja keuangan perusahaan (Y) secara parsial.Variabel interaksi kepemilikan manajerial dengan kebijakan dividen memiliki nilai signifikansi sebesar 0,901. Nilai signifikansi sebesar 0,901 lebih besar dari tingkat signifikansi 
0,05 atau nilai Sig. 0,901 > 0,05, sehingga dapat dikatakan bahwa $\mathrm{H}_{1}$ ditolak. Hal ini berarti bahwa kebijakan dividen $\left(\mathrm{X}_{3}\right)$ tidak mampu memoderasi pengaruh kepemilikan manajerial $\left(\mathrm{X}_{1}\right)$ terhadap kinerja keuangan perusahaan $(\mathrm{Y})$.Variabel interaksi kepemilikan institusional dengan kebijakan dividen memiliki nilai signifikansi sebesar 0,000. Nilai signifikansi sebesar 0,000 lebih kecil dari tingkat signifikansi 0,05 atau nilai Sig. 0,000 $<0,05$, sehingga dapat dikatakan bahwa $\mathrm{H}_{1}$ diterima. Hal ini berarti bahwa kebijakan dividen $\left(\mathrm{X}_{3}\right)$ mampu meperkuat pengaruh kepemilikan institusional $\left(\mathrm{X}_{2}\right)$ terhadap kinerja keuangan perusahaan (Y).

Penelitian ini mendapatkan hasil kepemilikan manajerial $\left(\mathrm{X}_{1}\right)$ memiliki nilai signifikansi sebesar 0,936. Nilai signifikansi sebesar 0,936 lebih besar dari tingkat signifikansi 0,05 atau nilai Sig. 0,936 > 0,05, sehingga dapat dikatakan bahwa $\mathrm{H}_{1}$ ditolak, yaitu kepemilikan manajerial tidak berpengaruh terhadap kinerja keuangan perusahaan pada perusahaan perbankan yang terdaftar di Bursa Efek Indonesia. Hal ini berarti semakin tinggi kepemilikan manajerial maka kinerja keuangan perusahaan akan menurun. Hasil penelitian ini tidak mendukung teori keagenan, dimana pada teori keagenan disebutkan bahwa adanya kepemilikan manajerial akan meningkatkan kinerja keuangan perusahaan karena dengan adanya kepemilikan manajerial akan mensejajarkan kepentingan manajemen dengan pemegang saham sehingga manajer akan mendapatkan dampak langsung dari keputusan yang diambilnya. Proporsi kepemilikan manajerial pada perusahaan perbankan yang menjadi sampel penelitian ini masih relatif rendah. Proporsi kepemilikan yang rendah menyebabkan manajemen kurang merasakan 
secara langsung manfaat dari pengambilan keputusan yang diambil pihak manajer.Hasil penelitian ini sejalan dengan hasil penelitian oleh Aprianingsih (2016), Rachman (2014), dan Wida (2014) yang menyatakan bahwa kepemilikan manajerial berpengaruh negatif terhadap kinerja keuangan perusahaan.

Penelitian ini mendapatkan hasil kepemilikan institusional $\left(\mathrm{X}_{2}\right)$ memiliki nilai signifikansi sebesar 0,000. Nilai signifikansi sebesar 0,000 lebih kecil dari tingkat signifikansi 0,05 atau nilai Sig. 0,000 < 0,05, sehingga dapat dikatakan bahwa $\mathrm{H}_{2}$ diterima, yaitu kepemilikan institusional berpengaruh terhadap kinerja keuangan perusahaan pada perusahaan perbankan yang terdaftar di Bursa Efek Indonesia. Hal ini berarti semakin tinggi kepemilikan institusional maka semakin baik kinerja keuangan perusahaan.Hasil penelitian ini mendukung teori keagenan, dimana dalam teori keagenan dikatakan bahwa dengan adanya kepemilikan institusional dalam suatu perusahaan akan menciptakan mekanisme monitoring (pengawasan) yang lebih tinggi sehingga manajer akan lebih hati-hati dalam melakukan pengelolaan keuangan perusahaan. Hasil penelitian ini konsisten dengan hasil penelitian oleh Dewi (2017), Hermiyetti dan Katlanis (2017). Affes (2013), dan Abbasi et al. (2012) yaitu kepemilikan institusional berpengaruh positif dan signifikan terhadap kinerja keuangan perusahaan.

Hasil penelitian ini menunjukkan bahwa kebijakan dividen tidak mampu memperkuat pengaruh kepemilikan manajerial terhadap kinerja keuangan perusahaan pada perusahaan perbankan yang terdaftar di Bursa Efek Indonesia yang memiliki arti $\mathrm{H}_{3}$ ditolak. Hal ini berarti kepemilikan manajerial tidak berpengaruh terhadap kinerja keuangan walaupun dalam suatu perusahaan 
terdapat kebijakan dividen. Hasil penelitian ini tidak mendukung teori sinyal dalam penelitian ini, dimana dalam teori sinyal dikatakan kebijakan dividen dapat memberikan sinyal kepada investor terhadap harga saham. Kebijakan dividen juga akan mempengaruhi manajer dalam meminimalisir asimetri informasi yang terjadi karena manajer memiliki kepentingan yang sama dengan investor yaitu dividend yield yang tinggi. Tandelilin (2003) menemukan tidak adanya pengaruh dari kebijakan dividen terhadap kepemilikan manajerial, dimana manajer cenderung mengutamakan faktor risiko daripada return atas kepemilikan saham di perusahaan tempatnya bekerja untuk meminimalisasi risiko investasi personalnya.

Hasil penelitian ini menunjukkan bahwa kebijakan dividen mampu memoderasi pengaruh kepemilikan institusional terhadap kinerja keuangan perusahaan pada perusahaan perbankan yang terdaftar di Bursa Efek Indonesia yang memiliki arti $\mathrm{H}_{4}$ diterima. Hal ini berarti dengan adanya kebijakan dividen dalam suatu perusahaan mampu memperkuat pengaruh kepemilikan institusional terhadap kinerja keuangan perusahaan.Hasil penelitian ini sesuai dengan teori sinyal dalam penelitian ini, dimana kebijakandividenakan menjadi sebuah sinyal informasi mengenai apa yang sudah dilakukan oleh manajemen. Hal tersebut dapat dilihat melalui seberapa besar laba yang diperoleh perusahaan, laba tersebut menunjukkan seberapa baik kinerja keuangan perusahaan dalam menarik minat investor untuk menanamkan modalnya.Hasil penelitian ini sejalan dengan hasil penelitian yang dilakukan oleh Ismiyanti dan Hanafi (2003) mendapatkan hasil bahwa kebijakan dividen dan kepemilikan institusional memiliki hubungan yang positif. 
Pada penelitian ini, kebijakan dividen bukan hanya sebagai variabel pemoderasi tetapi juga sebagai quasi moderator. Menurut Ghozali (2011) quasi moderator (moderator semu) yaitu variabel moderator berfungsi sebagai variabel predictor (independen) dan sekaligus juga berinteraksi dengan variabel predictor lainnya.Hasil penelitian ini menunjukkan bahwa kebijakan dividen berpengaruh terhadap kinerja keuangan perusahaan pada perusahaan perbankan yang terdaftar di Bursa Efek Indonesia. Hal ini berarti semakin besar dividen yang dibagikan oleh perusahaan maka akan semakin baik kinerja keuangan perusahaan. Kebijakan dividen pada penelitian ini mendukung teori sinyal yaitu manajer sebagai agen akanberusaha memberikan informasi mengenai hasil yang telah dicapai perusahaan melalui laporan keuangan yang memuat kinerja keuangan perusahaan. Pembayaran dividen kepada pemegang saham dapat mengurangi sumber daya yang ada dibawah penguasaan manajer, namun kebijakan ini akan dapat menjadi fungsi pengawasan pasar modal terhadap perilaku manajer pada saat perusahaan membutuhkan dana dari pemegang saham (Arumsari dkk., 2014). Hasil penelitian ini konsisten dengan hasil penelitian oleh Arumsari dkk., (2014), Uwuigbe, Jafaru, dan Ayaji (2012) serta Adediran dan Alade (2013) yang menyatakan bahwa kebijakan dividen berpengaruh terhadap kinerja keuangan perusahaan.

Hasil yang diperoleh dari penelitian ini yaitu kepemilikan institusional berpengaruh positif terhadap kinerja keuangan perusahaan. Hal ini berarti bahwa hasil penelitian ini mendukung teori keagenan yang mengatakan bahwa kepemilikan institusional dapat mengurangi konflik keagenan yang terjadi di sebuah perusahaan dengan meningkatkan kepemilikan saham oleh pihak 
institusi.Kepemilikan manajerial berpengaruh negatif terhadap kinerja keuangan perusahaan yang berarti bahwa hasil penelitian ini tidak mendukung teori keagenan dan teori sinyal pada penelitian ini. Penelitian ini juga memperoleh hasil bahwa kebijakan dividen dapat memperkuat pengaruh kepemilikan institusional terhadap kinerja keuangan perusahaan. Hal ini berarti bahwa hasil penelitian ini memdukung teori sinyal yang mengatakan bahwa kebijakan dividenakan menjadi sebuah sinyal bagi investor sehingga dengan adanya kebijakan dividen akan menarik investor melalui laporan keuangan perusahaan.

Pada penelitian ini diperoleh hasil bahwa kepemilikan institusional memiliki pengaruh paling tinggi pada penelitian ini. Berdasarkan hasil penelitian ini sebaiknya perusahaan perbankan mulai untuk menambah persentase kepemilikan pada pihak institusi. Bertambahnya kepemilikan institusional akan membuat mekanisme pengawasan terhadap tindakan oportusnistik yang dilakukan manajer perusahaan dapat di minimalisir sehingga dapat meningkatkan kinerja keuangan perusahaan. Penelitian ini memperoleh hasil bahwa kebijakan dividen mampu memperkuat pengaruh kepemilikan institusional terhadap kinerja keuangan perusahaan. Berdasarkan hasil penelitian tersebut sebaiknya perusahaan perbankan mengadakan kebijakan dividen sebagai sinyal dan dorongan bagi pihak institusi dalam menjalankan mekanisme monitoringnya sehingga kinerja keuangan perusahaan yang dilihat dari laba perusahaan terus meningkat dan pihak institusi mendapatkan dividend yield yang tinggi. 


\section{SIMPULAN}

Berdasarkan hasil analisis pada pembahasan di bab-bab sebelumnya, maka dapat disimpulkan kepemilikan manajerial pada perusahaan perbankan yang terdaftar di Bursa Efek Indonesia pada tahun 2012-2016 berpengaruh negatif terhadap kinerja keuangan perusahaan. Proporsi kepemilikan manajerial yang relatif rendah pada penelitian ini menyebabkan manajemen kurang merasakan secara langsung manfaat dari pengambilan keputusan yang diambil pihak manajer.Kepemilikan institusional pada perusahaan perbankan yang terdaftar di Bursa Efek Indonesia pada tahun 2012-2016 berpengaruh positif terhadap kinerja keuangan perusahaan. Meningkatnya kepemilikan institusional akan meningkatkan mekanisme monitoring pada perusahaan sehingga dapat memperkecil tindakan oportunistik manajer.

Kebijakan dividen tidak mampu memoderasi pengaruh kepemilikan manajerial terhadap kinerja keuangan perusahaan. Hal ini disebabkan karena kebijakan dividenpada suatu perusahaan merupakan sebagai mekanisme pengawasan, sehingga dengan ada ataupun tidak adanya kebijakan dividen tidak akan berpengaruh dengan kepemilikan saham oleh manajer.Kebijakan dividen mampu memoderasi pengaruh kepemilikan institusional terhadap kinerja keuangan perusahaan. Hal ini disebabkan karena kebijakan dividenpada suatu perusahaan akan menjadi sinyal bagi investor dan mendorong pihak institusiuntuk terus mengawasi pihak manajemen dalam mengelola keuangan mereka sehingga dapat meningkatkan kinerja keuangan perusahaan 
Saran yang dapat direkomendasikan adalah meningkatkan persentase kepemilikan institusional dalam suatu perusahaan. Hal ini dikarenakan peningkatan kepemilikan institusional dalam suatu perusahaan akan meningkatkan tingkat mekanisme monitoring sehingga dapat meminimalisir tindakan oportunistik manajer. Selain itu, adanya kebijakan dividen juga akan memperkuat pengaruh kepemilikan institusional terhadap kinerja keuangan perusahaan karena kebijakan dividen akan menjadi sinyal dan dorongan kepada pihak institusi yang juga merupakan investor perusahaan untuk tetap menanamkan modalnya dan mendorong mekanisme monitoring sehingga kinerja keuangan perusahaan yang dilihat dari laba perusahaan meningkat.

\section{REFERENSI}

Abbasi, M. et al. 2012. Impact of Corporate Governance Mechanism on Firm Value: Evidence From The Food Industry In Iran. Journal of Basic and Applied Scientific Research, 2 (5), 4712-4721.

Adediran. S. A., Alade S. O. 2013. Dividend Policy and Corporate Performance in Nigeria. American Journal Of Social And Management Sciences, 4 (2), 7177.

Affes, Habib and Nourchene Hamza Hakim. 2013. Ownership Structure and Performance of the Listed Tunisian Companies. Business and Economic Research, 3(2), 218-235.

Almilia, Luciana Spica,Meliza Silvy SpicaAlmilia, dan Meliza Silvy. 2006. Analisis Kebijakan Dividen dan Kebijakan Leverage terhadap Prediksi Kepemilikan Manajerial dengan Teknik Analisis Multinomial Logit. Jurnal Akuntansi dan Bisnis, 6(1).

Aprianingsih, Astri. 2016. Pengaruh Penerapan Good Corporate Governance, Struktur Kepemilikan, dan Ukuran Perusahaan Terhadap Kinerja Keuangan Perbankan Yang Terdaftar di Bursa Efek Indonesia Periode 2011-2014. Skripsi Universitas Negeri Yogyakarta. 
Arumsari, Yuni Kusuma, Djumahir, dan Siti Aisjah. 2014. Pengaruh Kepemilikan Manajerial, Kebijakan Utang, Kebijakan Dividen Terhadap Kinerja Keuangan dan Biaya Agensi (Studi Pada Perusahaan Manufaktur Yang Terdaftar Di Bursa Efek Indonesia).Jurnal Wawasan Manajemen, 2 (2).

Brigham, Eugene F and Joel F. Houston. 2009. Fundamentals of Financial Management. 12th Edition. Mason: South-Westtern Cengage Learning.

Darmawi, Hermawan. 2006. Pasar Finansial dan Lembaga-Lembaga Finansial. Jakarta: Bumi Aksara.

Dermawan, Sjahrial. 2008. Manajemen Keuangan Lanjutan. Edisi Kedua. Jakarta: Mitra Wacana Media.

Dewi, Sisca Christianty. 2008. Pengaruh Kepemilikan Manajerial, Kepemilikan Institusional, Kebijakan Utang, Profitabilitas, dan Ukuran Perusahaan terhadap Kebijakan Dividen. Jurnal Bisnis dan Akuntansi, 10(1), 47-58.

Dewi, Pande Enda Rastina. 2017. Pengaruh Penerapan Gcg Dan Ukuran Perusahaan Terhadap Kinerja Keuangan Perbankan di BEI Periode 20132016. E-Jurnal Akuntansi Universitas Udayana, 21 (1), 310-329.

Fahmi, Irham. 2012. Analisis Kinerja Keuangan. Bandung: Alfabeta.

Ghozali. 2011. Aplikasi Analisis Multivariate dengan Program IBM SPSS 19. Semarang: Badan Penerbit Universitas Diponegoro.

Haris Wibisono. 2004. Pengaruh Manajemen Laba terhadap Kinerja Perusahaan di Seputar Seasoned Equity Offerings (Studi Empiris di Bursa Efek Jakarta). Tesis Universitas Diponegoro, Jawa Tengah.

Hermiyetti, dan Katlanis, Erlinda. 2017. Pengaruh Kepemilikan Manajerial, Kepemilikan Institusional, Kepemilikan Asing, dan Komite Audit Terhadap Kinerja Keuangan Perusahaan (Survei Terhadap Perusahaan Manufaktur yang Terdaftar di Bursa Efek Indonesia pada Periode 2009-2012).Jurnal IlmiahUniversitas Bakrie.

Imanta, D., dan Satwiko, R. 2011.Faktor-Faktor yang Mempengaruhi Kepemilikan Manajerial. Jurnal Bisnis dan Akuntansi, 13 (1), 67-80.

Indarti, MG. Kentris dan Lusi Extaliyus. 2013. Pengaruh Corporate Governance Preception Index (CGPI), Struktur Kepemilikan, dan Ukuran Perusahaan terhadap Kinerja Keuangan. Jurnal Bisnis dan Ekonomi, 20 (2). 
Ismiyanti, F., dan Hanafi, Mamduh. M. 2003. Kepemilikan Manajerial, Kepemilikan Institusional, Risiko, Kebijakan Utang dan Kebijakan Dividen: Analisis Persamaan Simultan. Simposium Nasional Akuntansi VI.

Jama'an. 2008. Pengaruh Mekanisme Corporate Governance dan Kualitas Kantor Akuntan Publik Terhadap Integritas Informasi Laporan Keuangan (Studi Pada Perusahaan Public di BEJ). Tesis Universitas Diponegoro, Jawa Tengah.

Jensen, Michael C. dan Meckling. William H. 1976. Thery of The Firm: Managerial Behavior, Agency Cost, and Ownership Structure.Jurnal of Financial Economics, 3 (4), 305-360.

Jumingan. 2009. Analisis Laporan Keuangan. Jakarta: Bumi Aksara.

Manneh, Marwan Abu \& Kamal Naser. 2015.Determinants of Corporate Dividends Policy: Evidence from an Emerging Economy.International Journal of Economics and Finance, 7 (7), 229-239.

Margaretha, F., \& Asmariani, A. 2009. Faktor-Faktor Agency Theory yang Mempengaruhi Hutang. Media Riset Bisnis dan Manajemen, 9 (1), 1-20.

Marisanti. 2012. Analisis hubungan profitabilitas terhadap pengungkapan modal intelektual capital. Diponegoro Jurnal of accounting.

Martono dan D.Agus Harjito. 2000. Manajemen Keuangan. Edisi Pertama. Yogyakarta: Ekonisia.

Masdupi. 2005.Analisis Dampak struktur kepemilikan pada Kebijakan Hutang dalam Mengontrol Konflik Keagenan.Jurnal Ekonomi Bisnis,20 (1),56-69.

Modigliani, Franco, \& Miller M. H. 1963.The cost of Capital, Corporation finance, and the Theory of Invesment. American Economic. Review, 53, 433-443.

Moh'd, M.A., L.G. Perry, dan J.N. Rimbey. 1998. The Impact of Ownership Structure on Corporate Dept Policy: A Time Series Cross-Sectional Analysis. The Financial Review, 33, 85-99.

Morris, R. D. 1987. Signaling, agency theory and accounting policy. Accounting and Business Research, 8 (69), 47-56.

Nafi'ah, Zumroatun. 2013. Analisis Faktor-faktor yang MempengaruhiKebijakan Dividen dan Dampaknya terhadap Nilai Perusahaan pada Perusahaan Manufaktur yang Tercatat di Bursa Efek Indonesia Tahun 2008-2010. Jurnal STIE Semarang, 5 (3). 
Purwantini, V. Titi. 2008. Pengaruh Mekanisme Good Corporate Governance Terhadap Nilai Perusahaan dan Kinerja Keuangan Perusahaan (Studi pada Perusahaan-Perusahaan Manufaktur yang Terdaftar di Bursa Efek Indonesia).

Rachman, Reza Aditya. 2014. Pengaruh Kepemilikan Manajerial dan Kepemilikan Institusional Terhadap Kinerja Keuangan pada Perusahaan Manufaktur yang Terdaftar di Bursa Efek Indonesia (BEI). Artikel Ilmiah Sekolah Tinggi Ilmu Ekonomi Perbarnas, Surabaya.

Ratnawati, Kusuma. 2001. Analisis Perbedaan Struktur Modal dan Faktor Intern, Faktor Ekstern, Perushaaan Industri PMA dan PMDN di BEJ. Disertasi Universitas Airlangga, Surabaya.

Rivai,Veithzal, dkk.2012. Commercial Bank Management: Manajemen Perbankan Dari Teori Ke Praktik. Edisi 1. Jakarta: Rajawali Pers.

Ross, S.A. 1977. The Determination of Financial Structure: the Incentive Signalling Approach. Bell Journal of Economics, 8 (1), 23-40.

Sam'ani. 2008. Pengaruh Good Corporate Governance dan Leverage Terhadap Kinerja Keuangan Pada Perbankan Yang Terdaftar di Bursa Efek Indonesia (BEI) tahun 2004 - 2007. Tesis Magister Manajemen Universitas Diponegoro, Jawa Tengah.

Siregar, S. V., dan S. Utama. 2005. Pengaruh Struktur Kepemilikan, Ukuran Perusahaan dan Praktek Corporate Governance terhadap Pengelolaan Laba. Jurnal Riset Akuntansi Indonesia, 9 (3).

Sugiyono. 2014. Metode Penelitian Bisnis. Bandung: Alfabeta.

Tandelilin, E. 2003, Analisis Interdependensi Kebijakan Leverage, Dividen dan Kepemilikan Manajerial: Perspektif Keagenan.Working Paper QUE Manajemen, Universitas Gadjah Mada, Yogyakarta.

Tarigan, Josua dan Yulius Yogi Christiawan. 2007. Kepemilikan Manajerial: Kebijakan Utang, dan Nilai Perusahaan. Jurnal Akuntansi dan Keuangan, 9(1), 1-8.

Umalomwa U, \& Olamide O. 2012. An Empirical of the Relationship between Ownership Structure and the Performance of Firms in Nigeria. International Business Research, 5(1).

Utama, Made Suyana. 2009. Buku Ajar Aplikasi Analisis Kuantitatif. Denpasar: Sastra Utama. 
Uwuigbe, Uwalomwa., Jimoh, Jafaru., Anijesushola, Ajayi. 2012. Dividend Policy And Firm Performance: A Study Of Listed Firms In Nigeria. Accounting Analysis Journal, 1 (2).

Vernon J. Richardson. 1998.Information Asymmetry and Earnings Management: Some Evidence. Paper University of Kansas.

Vidyantie, D.N., dan Handayani, R. 2006. The Analysis of The Effect of Debt Policy, Dividend Policy, Institusional Investor, Business Risk, Firm Size and Earning Volatility to Managerial Ownership Based on Agency Theory Perspective.Jurnal Bisnis dan Akuntansi, 8 (2), 19-33.

Waskito, Titis. 2014. Pengaruh Struktur Kepemilikan Manajerial, Kepemilikan Institusional, Dan Ukuran Perusahaan Terhadap Kinerja Keuangan (Ditinjau Dari Perusahaan Manufaktur Yang Terdaftar Di Bursa Efek Indonesia Tahun 2008 Sampai Dengan Tahun 2011). Skripsi Universitas Muhammadiyah Surakarta, Jawa Tengah.

Wida P. D, Ni Putu. 2014. Pengaruh Kepemilikan Manajerial dan Kepemilikan Institusional Terhadap Nilai Perusahaan. E-Jurnal Akuntansi Universitas Udayana, 9 (3), 575-590.

Widarjo, Wahyu. 2010. Pengaruh Ownership Retention, Investasi dan Proceeds dan Reputasi Auditor terhadap Nilai Perusahaan dengan Kepemilikan Manajerial dan Institusional sebagai Variabel Pemoderasi. Tesis Universitas Sebelas Maret, Jawa Tengah.

Widiastuti,Marselina, Pranata P. Midiastuty, dan Eddy Suranta. 2013. Dividend Policy and Foreign Ownership. Simposium Nasional Akuntansi XVI, 34013423.

Wolk, H.I. and M.G. Tearney. 1997. Accounting Theory: A conceptual and Institutional Approach. Edisi keempat. International Thomson Publishing. 